\title{
SAR11 dominance among metabolically active low nucleic acid bacterioplankton in surface waters along an Atlantic meridional transect
}

\author{
I. Mary ${ }^{1}$, J. L. Heywood ${ }^{1}$, B. M. Fuchs' ${ }^{2}$ R. Amann' ${ }^{2}$, G. A. $\operatorname{Tarran}^{3}$, P. H. Burkill ${ }^{1}$, \\ M. V. Zubkov ${ }^{1, *}$ \\ ${ }^{1}$ National Oceanography Centre, University of Southampton, Waterfront Campus, European Way, Southampton SO14 3ZH, UK \\ ${ }^{2}$ Max Planck Institute for Marine Microbiology, Celsiusstrasse 1, 28359 Bremen, Germany \\ ${ }^{3}$ Plymouth Marine Laboratory, Prospect Place, The Hoe, Plymouth PL1 3DH, UK
}

\begin{abstract}
Low nucleic acid (LNA) bacterioplankton (sorted by flow cytometry) were characterised in surface water samples along a meridional transect from $48^{\circ} \mathrm{N}$ to $40^{\circ} \mathrm{S}$ across the Atlantic Ocean. The LNA bacterioplankton abundance and metabolic activity, assessed by their ${ }^{35}$ S-methionine uptake rate, were similar along the transect, representing $36 \pm 6$ and $36 \pm 11 \%$ of total bacterioplankton, respectively. Fluorescence in situ hybridisation analysis of the flow-sorted cells revealed that the LNA bacterioplankton population was dominated $(59 \pm 4 \%)$ by and contained virtually all the identifiable SAR11 clade cells throughout the Atlantic Ocean. Therefore, the present study provides ecological characterisation of this flow-sorted group and suggests both phylogenetic and functional constancy of the LNA bacterioplankton at the basin-scale.
\end{abstract}

KEY WORDS: Flow cytometry sorting • Cell metabolic activity · SAR11 clade · CARD-FISH · Radioactive tracer labelling · Atlantic Ocean

\section{INTRODUCTION}

The nucleic acid content of individual cells has been extensively estimated to discriminate between bacterioplankton (Bpl) cells with high nucleic acid content (HNA) and those with low nucleic acid content (LNA) using flow cytometry (Li et al. 1995, Gasol et al. 1999, Lebaron et al. 2001, Zubkov et al. 2001a,b). HNA bacteria have been regarded as the dynamic members of the bacterial assemblage (Gasol et al. 1999, Lebaron et al. 2001). However, the role of LNA cells has remained controversial, with different studies describing them as inactive, dead or fragmented (Lebaron et al. 2001), or as viable cells as active as other members of the community (Zubkov et al. 2001b).

The phylogenetic and functional relevance of cytometrically defined groups still remains poorly studied. Recently, it was shown that LNA populations are often dominated by a small number of clades (Fuchs et al.
2005). For example, sequences related to the SAR11 clade dominated the 16S rRNA gene clone library of LNA cells (sorted by flow cytometry) sampled from the southern oligotrophic waters of the Arabian Sea. Moreover, the only cultured representative of the SAR11 clade, Pelagibacter ubique (Rappe et al. 2002), has the smallest genome size among free-living bacteria (Giovannoni et al. 2005).

In the present study, using the flow cytometry sorting approach, we tested 2 hypotheses: (1) that the LNA group is dominated by a single phylogenetic group, SAR11 clade; and (2) that this group dominates the bacterioplankton uptake of dissolved labile organic nutrients such as amino acids. The hypotheses were tested on a transatlantic transect through several oceanic provinces (see Fig. 1), i.e. from the Northern Atlantic Gyre (NAG), into the Mauritanian upwelling region, through tropical and equatorial Atlantic waters, into the Southern Atlantic Gyre (SAG), and 
into the South Subtropical Frontal Zone (SSFZ, Belkin \& Gordon 1996). As it was not possible to work on every sample collected along the transect, we selected representative samples for a basin-scale study.

\section{MATERIALS AND METHODS}

Sampling area. The material was collected and measurements were made primarily on one Atlantic Meridional Transect (AMT) cruise on board the RRS 'James Clark Ross', cruise no. JR91, transect no. AMT13, in September and October 2003 (Fig. 1). Up to 24 seawater samples were collected approximately every $12 \mathrm{~h}$ from a range of depths in the top $300 \mathrm{~m}$ using a rosette of $24 \times 201$ Niskin bottles mounted on a conductivity-temperature-density (CTD) profiler. The $\mathrm{Bpl}$ cells were routinely fixed with $1 \%$ paraformaldehyde (PFA) final concentration.

The abundance of Bpl was determined at every station (Heywood et al. 2006, Tarran et al. 2006), and for the present study 9 stations were chosen along the transect to represent the basin-scale range of surface waters (Fig. 1). The samples for the study of turnover rates of methionine (Met) by total bacterioplankton and by the LNA group sorted by flow cytometry were

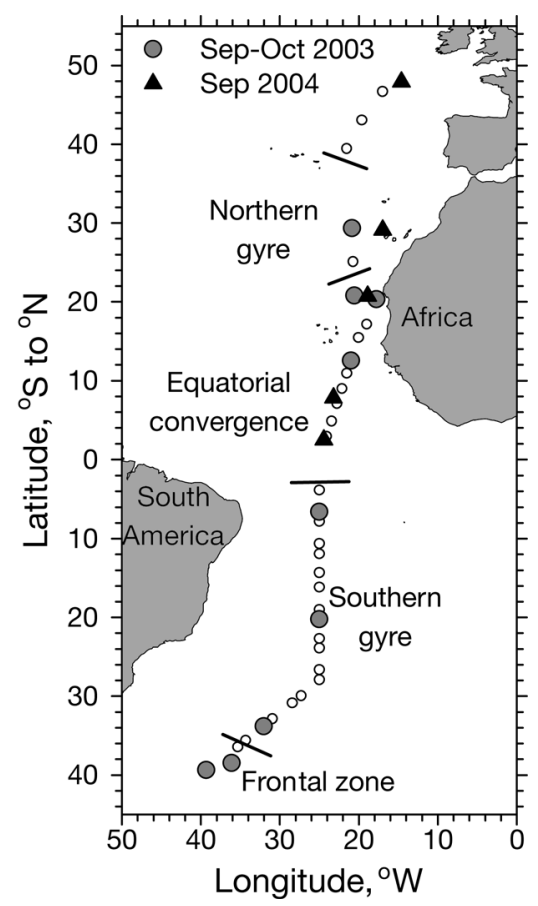

Fig. 1. Station locations and areas studied. $(0, \mathbf{\Lambda})$ Stations at which the low nucleic acid bacterioplankton cells (sorted by flow cytometry) were characterised, and (0) 15 additional stations occupied on cruise no. JR91, transect no. AMT-13, of RRS 'James Clark Ross' in 2003 and cruise no. D284, transect no. AMT-15, of RRS 'Discovery' in 2004 collected from depths of 3 to $7 \mathrm{~m}$. Methionine uptake was chosen because of the high specific activity of the ${ }^{35} \mathrm{~S}$-methionine precursor and because previous studies have shown that microbial uptake of this amino acid are strongly correlated with the uptake of other amino acids such as leucine (Zubkov et al. 2004). The analyses also included the phylogenetic affiliation of the flow-sorted LNA cells using fluorescence in situ hybridisation (FISH). To test that the results obtained from the selected stations were representative of the Atlantic surface waters, an additional 15 stations (Fig. 1) were included for comparison of the relative LNA abundance and Met uptake rates.

Additional samples for phylogenetic analyses of bacterioplankton were collected from the Northern Atlantic at 5 stations on a later cruise on the RRS 'Discovery', cruise no. D284, transect no. AMT-15, in September 2004 (Fig. 1) to evaluate the reproducibility of the observations made on transect no. AMT-13.

Bioassay of microbial uptake rates of methionine. The total microbial uptake rates of Met were estimated as described previously (Zubkov et al. 2004, Zubkov \& Tarran 2005). Briefly, the samples were initially collected into acid-washed $1 \mathrm{l}$ thermos flasks using acidsoaked silicone tubing and processed within $1 \mathrm{~h}$ after sampling. The L- $\left[{ }^{35} \mathrm{~S}\right] \mathrm{Met}\left(1000 \mathrm{Ci} \mathrm{mmol}^{-1}\right.$, Amersham) was added at a standard concentration of $0.13 \mathrm{nM}$ and diluted with non-labelled Met using a dilution series of $0.2,0.5,1.0,1.5$ and $2.0 \mathrm{nM}$. The rate of precursor uptake was calculated as the slope of the linear regression of radioactivity against incubation time and used to compute Met turnover time by dividing the amount of radioactivity added to a sample by the rate of its uptake per day. The resulting turnover times were plotted against a corresponding concentration of added amino acid and approximated using linear regression $\left(\mathrm{r}^{2}>0.97, \mathrm{p}<0.001, \mathrm{n}=5\right)$. The slope of the regression line gave an estimate of the absolute Met uptake rate of the $\mathrm{Bpl}\left(\mathrm{nM} \mathrm{Met} \mathrm{d}^{-1}\right)$.

Enumeration and flow cytometry sorting of isotopically labelled bacterioplankton cells. Amino acid uptake by the bacterioplankton groups was determined using ${ }^{35} \mathrm{~S}-\mathrm{Met}$ as described previously (Zubkov et al. 2004). The uptake of ${ }^{35} \mathrm{~S}-\mathrm{Met}$ at the added concentration $(0.84 \pm 0.12 \mathrm{nM})$ always lay within the linear uptake range of the assayed bacterioplankton. Five replicated $1.6 \mathrm{ml}$ samples were incubated at in situ temperature in the dark, fixed with $1 \%$ PFA after $3 \mathrm{~h}$, and then further incubated at $2^{\circ} \mathrm{C}$ for $24 \mathrm{~h}$ and stored frozen at $-80^{\circ} \mathrm{C}$ before being analysed ashore. The long incubation time of $3 \mathrm{~h}$ was chosen to maximise the amount of radiolabel taken up by bacterioplankton cells, since the sorting by flow cytometry was done 2 mo after sample collection and the ${ }^{35} \mathrm{~S}$ isotope has a relatively short half-life of $87.5 \mathrm{~d}$. 
The LNA group and Bpl (see Fig. 2) were enumerated by flow cytometry, using a FACSort instrument (Becton Dickinson) with standard laser and detection configuration. Thawed samples were stained with SYBR Green I DNA dye (Marie et al. 1997), and yellow-green $0.5 \mu \mathrm{m}$ bead standards (Fluoresbrite Microparticles) were used in all analyses as an internal standard. The FACSort was set at single-cell sort mode (the highest sorting purity of the instrument) and the target cells were gated and flow sorted at a rate of 10 to 250 particles $\mathrm{s}^{-1}$. Sorted cells were collected onto $0.2 \mu \mathrm{m}$ pore size nylon filters and washed with deionised water. Radioactivity retained on the filters was measured as counts per minute (cpm) using an ultra-low level liquid scintillation counter (1220 Quantulus), and disintegrations per minute (dpm) were calculated to correct for radioactive decay. Three proportional numbers of the LNA and average Bpl cells (from 2, 4 and $6 \times 10^{3}$ cells to 20,40 and $60 \times 10^{3}$ cells) were sorted, and the mean cellular ${ }^{35} \mathrm{~S}-$ Met uptake was determined as the slope of the linear regression of radioactivity against the number of sorted bacterial cells (dpm cell ${ }^{-1}$ ).

Sorting purity was assessed routinely by sorting 1 type of calibration bead (Polysciences) from a mixture of 2 yellow-green bead sizes ( 0.5 and $2 \mu$ m diameter) and flow cytometry reanalysis of the sorted material. The sorted material was $99 \%$ enriched with the targeted beads.

The cell and population-specific relative and absolute activities of the LNA group were calculated as previously described in detail for cyanobacteria (Zubkov et al. 2004, Zubkov \& Tarran 2005). Briefly, the ${ }^{35} \mathrm{~S}$-Met uptake of LNA and Bpl populations were determined by multiplying the mean radioactivity per cell of the sorted group by the abundance of the group (dpm cell ${ }^{-1} \times$ cells $\left.\mathrm{ml}^{-1}=\mathrm{dpm} \mathrm{ml} \mathrm{m}^{-1}\right)$. The corresponding relative ${ }^{35} \mathrm{~S}$-Met uptake of the LNA population was calculated as the LNA fraction of the $\mathrm{Bpl}{ }^{35} \mathrm{~S}$ Met uptake. The absolute Met uptake of the LNA population was calculated as the LNA fraction of the Bpl ${ }^{35} \mathrm{~S}-$ Met uptake multiplied by the absolute Met uptake of $\mathrm{Bpl}\left(\mathrm{nM} \mathrm{Met} \mathrm{d}^{-1}\right)$. The absolute cell Met uptake was calculated by dividing the absolute Met uptake of the LNA population by LNA abundance (amol Met cell ${ }^{-1} \mathrm{~d}^{-1}$ ).

Flow cytometry sorting of bacterioplankton cells for catalysed reporter deposition (CARD)-FISH analysis. The PFA-fixed LNA cells stained with SYBR Green were flow sorted using a MoFlo flow cytometer (DakoCytomation). For excitation, an Argon ion laser (Innova-A300) was tuned to $488 \mathrm{~nm}$ with an output power of $500 \mathrm{~mW}$. SSC was analysed through a $488 \pm$ $10 \mathrm{~nm}$ bandpass filter, green fluorescence (FL1) of SYBR Green-stained cells was measured through a
$530 \pm 20 \mathrm{~nm}$ bandpass filter. Online analysis was done on a bivariate dotplot diagram using the Summit software (DakoCytomation). The dotplot diagrams were used for defining sorting gates. Particle-free $(<0.2 \mu \mathrm{m})$ $0.1 \% \mathrm{NaCl}(\mathrm{w} / \mathrm{v})$ solution was used as a sheath fluid for sorting. Sheath fluid was pressurized at 60 psi (413 685 $\mathrm{Pa})$. The drop drive was set to $106770 \mathrm{~Hz}$ at an amplitude of around $11 \mathrm{~V}$ resulting in a drop delay of around 46 drops depending on the daily performance. The sort mode 'single one drop' was selected to get the highest sorting purity. The performance was evaluated by sorting a known number of beads onto microscopic slides which were subsequently enumerated under an epifluorescence microscope. Approximately $1 \times 10^{4}$ cells were sorted and subsequently filtered onto $0.2 \mu \mathrm{m}$ pore-size polycarbonate filters for FISH analysis as described previously (Zubkov et al. 2003).

CARD-FISH was performed as described previously (Pernthaler et al. 2002) with some modifications. Briefly, cells were embedded in low-gelling point agarose and permeabilised by subsequent treatment with lysozyme for $60 \mathrm{~min}$ at $37^{\circ} \mathrm{C}$ and achromopeptidase for a further $30 \mathrm{~min}$ at $37^{\circ} \mathrm{C}$. Next, the filters were washed in sterile water and then $96 \%$ (v/v) ethanol for 1 min each. Filter sections were submerged in the buffer-probe mix and incubated at $35^{\circ} \mathrm{C}$ on a rotation shaker for $2 \mathrm{~h}$. The hybridisation buffer and probe working solution (50 $\mathrm{ng} \mathrm{\mu l}^{-1}$ ) were mixed 300:1. The hybridisation buffer contained varying amounts of formamide, depending on the probe used (Table 1). Washing was done in $50 \mathrm{ml}$ of pre-warmed washing buffer with varying amounts of $\mathrm{NaCl}$, depending on the probe used (Table 1). After the washing step, filters were transferred into $15 \mathrm{ml}$ of $1 \times$ phosphate buffered saline (PBS) for $15 \mathrm{~min}$ at room temperature for equilibration. Tyramide signal amplification was performed using custom fluorescein isothiocyanate (FITC)-labeled tyramides (Pernthaler \& Amann 2004). One part of the tyramide solution was added to 300 parts of amplification buffer for $15 \mathrm{~min}$ at $37^{\circ} \mathrm{C}$ in the dark. The filters were then washed with $1 \times$ PBS for $15 \mathrm{~min}$ at room temperature followed by subsequent washes in sterile water and $96 \%$ ethanol for $1 \mathrm{~min}$. Counter-staining of CARD-FISH preparations with 4,6-diamidino-2-phenylindole (DAPI; $1 \mu \mathrm{g} \quad \mathrm{ml}^{-1}$ ), mounting, and microscopic evaluations were performed as described previously (Glöckner et al. 1996). Cells were counted under a Zeiss Axioplan II motorised epifluorescence microscope (Carl Zeiss), equipped with a $100 \times$ UV Plan Apochromat objective and excitation/emission filters 360/420 for DAPI and 490/515 for FITC and an automated image analysis system KS300 (Image Associates). At least 300 cells were counted per sorted sample. Probe-positive cells were presented as fractions of DAPI-stained cells. 
Table 1. FISH probes used in this study. \% FA: percentage of formamide in in situ hybridisation buffer; $\mathrm{NaCl}$ : $\mathrm{NaCl}$ concentration $(\mathrm{mM})$ in washing buffer

\begin{tabular}{|c|c|c|c|c|c|}
\hline Probe & Specificity & Sequence $\left(5^{\prime}-3^{\prime}\right)$ of probe & $\%$ FA & $\mathrm{NaCl}$ & Source \\
\hline EUBI-III & Bacteria & GCWGCCWCCCGTAGGWGT & 55 & 13 & $\begin{array}{l}\text { Amann et al. (1990), } \\
\text { Daims et al. (1999) }\end{array}$ \\
\hline Alf968 & Alphaproteobacteria & GGTAAGGTTCTGCGCGTT & 55 & 13 & Neef (1997) \\
\hline SAR11-441R & SAR11 clade & TACAGTCATTTTCTTCCCCGAC & 50 & 19 & Morris et al. (2002) \\
\hline CF319a & Cytophagales & TGGTCCGTGTCTCAGTAC & 50 & 19 & Manz et al. (1996) \\
\hline Gam42a & Gammaproteobacteria & GCCTTCCCACATCGTTT & 50 & 19 & Manz et al. (1992) \\
\hline HGC69a & Actinobacteria & TATAGTTACCACCGCCGT & 40 & 37 & Roller et al. (1994) \\
\hline Ros537 & Roseobacters and SAR83 & CAACGCTAACCСССТCC & 55 & 13 & Eilers et al. (2001) \\
\hline SAR86/ 1245 & Core cluster SAR86 & TTAGCGTCCGTCTGTAT & 50 & 19 & Zubkov et al. (2001b) \\
\hline
\end{tabular}
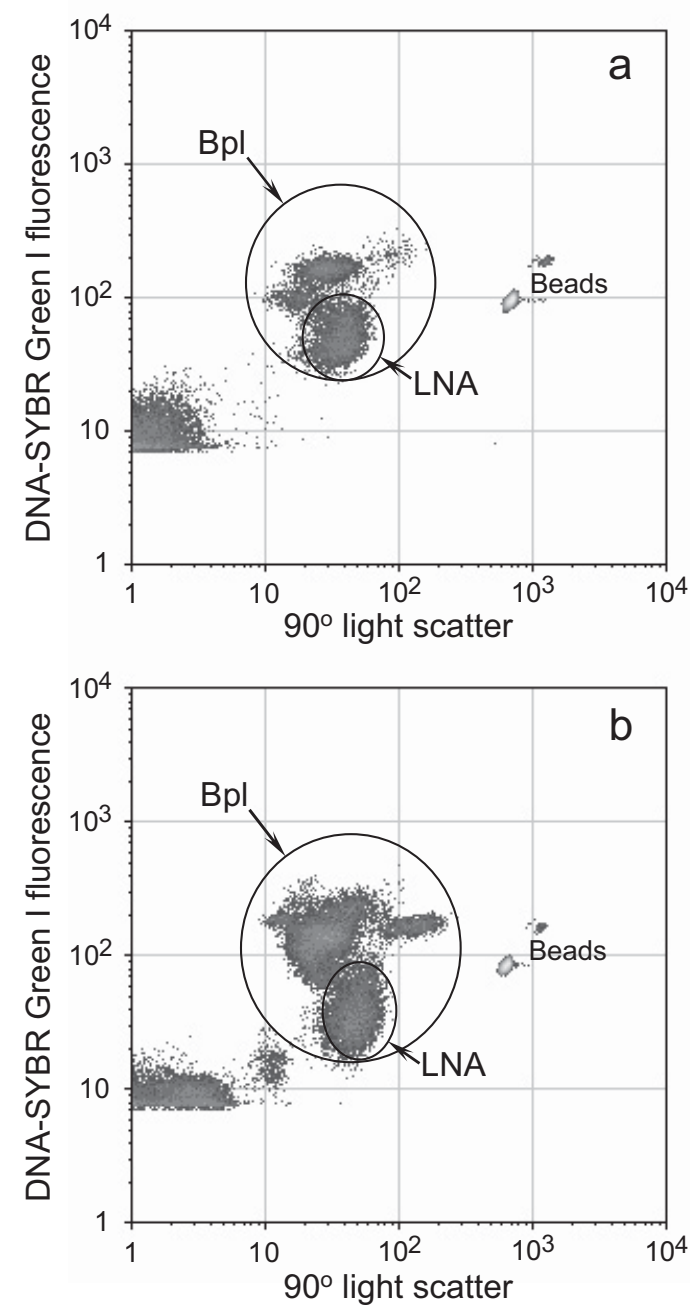

Fig. 2. Density plots of particle $90^{\circ}$ light scatter versus green fluorescence showing typical flow cytometric signatures of DNA-SYBR Green I-stained bacterioplankton populating surface waters of (a) the oligotrophic gyre and (b) temperate regions. Samples were collected from $6 \mathrm{~m}$ depth at $20^{\circ} 14^{\prime} \mathrm{S}$, $25^{\circ} \mathrm{W}$ and $38^{\circ} 29^{\prime} \mathrm{S}, 36^{\circ} 22^{\prime} \mathrm{W}$. Groups of cells with low nucleic acid content (LNA, sorted by flow cytometry) and total bacterioplankton $(\mathrm{Bpl})$ are indicated. Fluorescent beads $(0.5 \mu \mathrm{m}$ diameter) were used as an internal standard

\section{RESULTS AND DISCUSSION}

\section{Sorting bacterioplankton groups for molecular phylogenetic characterisation}

We analysed the phylogenetic composition of the flow-sorted LNA group of bacterioplankton (Fig. 2) using FISH.

Between 80 and $95 \%$ of the sorted cells and similarly 80 to $90 \%$ of unsorted cells were identified as bacteria (Fig. 3). The alphaproteobacteria numerically dominated (54 to $74 \%$ ) the cells sorted from the LNA group, and accounted for 19 to $50 \%$ of total bacterioplankton cells (Fig. 3a,b). Furthermore, the SAR11 clade (Giovannoni et al. 1990) dominated alphaproteobacteria, accounting for 51 to $66 \%$ of LNA cells and for 12 to $37 \%$ of the total bacterioplankton cells, respectively (Fig. 3a,b). Percentages of the SAR11 clade in the LNA group (Fig. 3a) were multiplied by the corresponding percentages of the LNA group in Bpl (Fig. 3c). The direct and indirect methods of estimating the SAR11 clade percentage in the Bpl agreed closely, $22 \pm 9$ and $21 \pm 3 \%$, respectively. The presence of SAR11 was also checked in the HNA population and no hybridised cells were detected (data not shown). The CARD-FISH analyses of LNA cells flow sorted from samples collected in the surface waters as well as at depths down to $115 \mathrm{~m}$ on the AMT-15 transect 1 yr later (Fig. 1) showed that the SAR11 clade dominated the LNA cluster, accounting for 57 to $74 \%$ of LNA $(66 \pm 6 \%, \mathrm{n}=8)$ confirming the AMT-13 observations.

This compositional constancy confirmed previous observations made on a smaller spatial scale in the northern North Sea (Zubkov et al. 2002), where the composition of Bpl within the groups also remained constant while the concentration of the groups varied considerably at the 10 to $100 \mathrm{~km}$ scale. The LNA group of Bpl obviously represented quite a stable SAR11 clade-dominated assemblage that was similar in different parts of the Atlantic Ocean. The SAR11 clade har- 

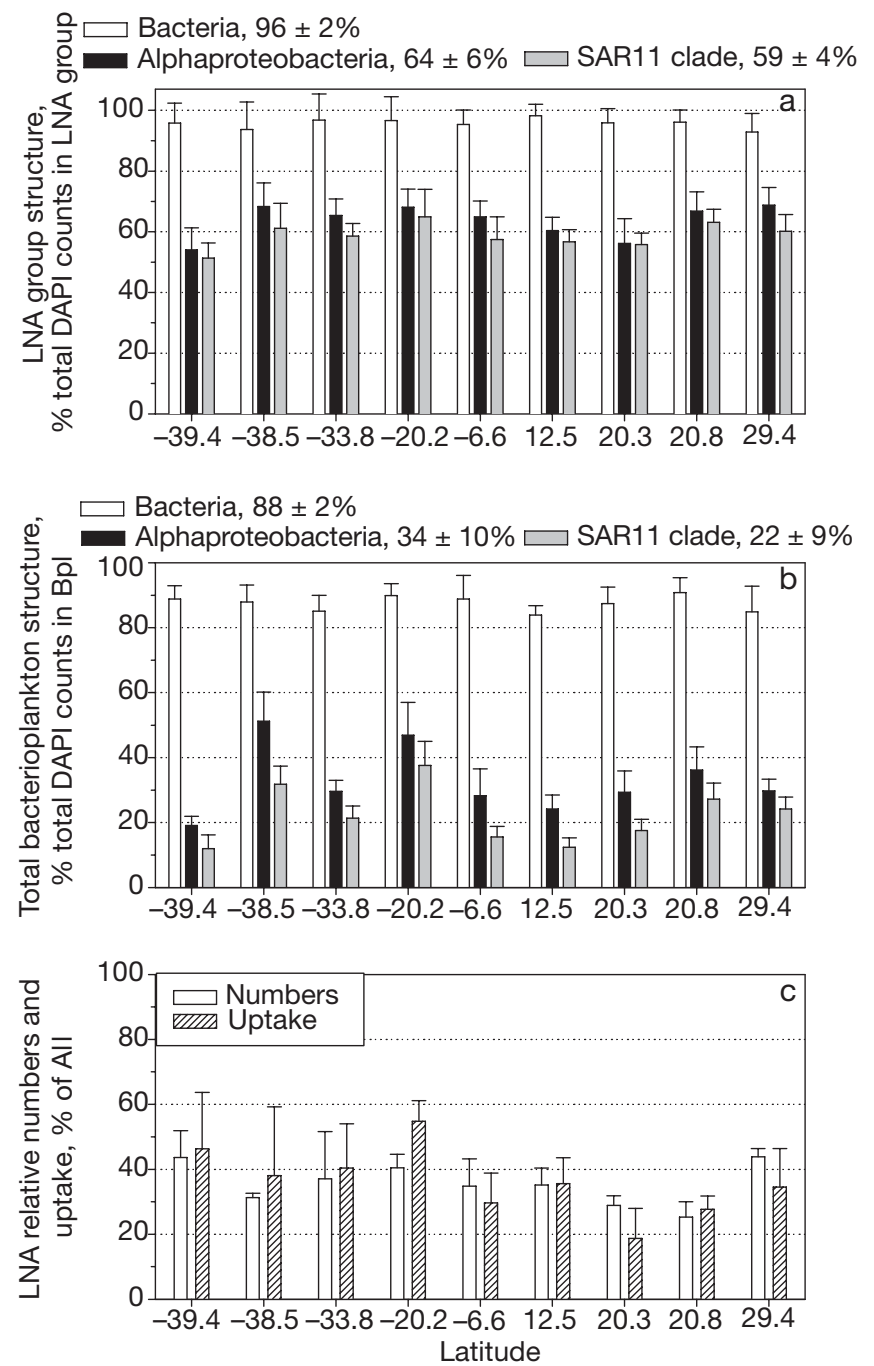

Fig. 3. Fluorescence in situ hybridisation (FISH) with (a) flowsorted cells from the low nucleic acid (LNA) group and (b) total bacterioplankton (Bpl). (c) LNA relative cell numbers and methionine uptake at different latitudes (negative values on $x$-axis correspond to ${ }^{\circ} \mathrm{S}$ ) along transect AMT-13. Hybridisation shown as percentage of probe-positive cells stained with DAPI. Probes were EUBI-III for bacteria, ALF968 for alphaproteobacteria and SAR11-441R for SAR11 clade (see Table 1 for details). Data are means +SD of several counts of independent hybridisations. Values in keys are average $\pm \mathrm{SD}$ of plotted values

bours a broad diversity, which is hard to resolve by specific FISH probes (Field et al. 1997). The SAR11 cells dominating habitats such as the Mauritanian upwelling region or the oxygen minimum zone of the Arabia Sea could phylogenetically differ from SAR11 cells inhabiting the surface waters of the open ocean (Fuchs et al. 2005). However, they all share the common feature of small genome size that segregates them into the LNA group of Bpl.
A wide variety of published and unpublished FISH probes specific to other major groups of marine bacterioplankton was applied (J. Heywood unpubl. data), but identification of the remaining 20 to $40 \%$ cells within the LNA group could not been achieved. There are 2 possible explanations. Firstly, the probe SAR11441 almost certainly underestimated the abundance of the SAR11 cells under the hybridisation conditions used. Secondly, up to $10-20 \%$ of bacterioplankton cells could be inaccessible to some horseradish peroxidase-labelled probes (B. Fuchs unpubl. data). Hence, the real detection gap could be narrower than 20 to $40 \%$. Presently, there are no other known bacterial clades that have a streamlined genome and metabolism similar to those of Pelagibacter ubique.

\section{LNA group abundance and methionine uptake rates}

Although the LNA and Bpl abundance and Met uptake rates along the transect varied by 10 - and 20 -fold, respectively (Fig. 4a,b), the cell Met uptake rates were less variable, varying about 3-fold (Fig. 4c). The LNA cell-specific Met uptake rates were significantly less variable than the cell-specific Met uptake of Prochlorococcus, the latter varied within 1 order of magnitude along the same transect (Zubkov et al. 2004). Surprisingly, the absolute LNA and Bpl uptake rates were not lower in the gyres and higher in the upwelling and frontal regions (Fig. 4). The LNA group comprised on average $36 \%$ of the Bpl numbers, and similarly the Met uptake rate of the LNA population was on average $36 \%$ that of the total bacterioplankton (Fig. 3c, Table 2). The results from the 9 selected stations were representative of the larger data set collected on the same cruise (Table 2). The relative Met uptake rates by the LNA cell were similar to those of an average Bpl cell. The station at $20.3^{\circ} \mathrm{N}, 17.77^{\circ} \mathrm{W}$, in the vicinity of the Mauritanian upwelling region, was the only site where the Met uptake of the LNA group was considerably lower than that of other bacterioplankton, probably because of strong competition for organic nutrients with the other, faster growing bacterioplankton groups (Figs. 3c \& 4).

Table 2. Comparison of relative parameters of flow-sorted low nucleic acid groups. Data are percentages of total, averaged for 9 selected (Select) representative stations and 24 (All) stations studied (Fig. 1) on cruise no. JR91, transect no. AMT-

13. Data are regression slopes \pm SD. Met: methionine

\begin{tabular}{|lcc|}
\hline Parameter & Select & All \\
\hline Number & $35.6 \pm 6.4$ & $37.4 \pm 4.9$ \\
Population Met uptake & $36.2 \pm 10.6$ & $37.3 \pm 8.1$ \\
Cell-specific Met uptake & $101.3 \pm 21.9$ & $99.8 \pm 18.4$ \\
\hline
\end{tabular}



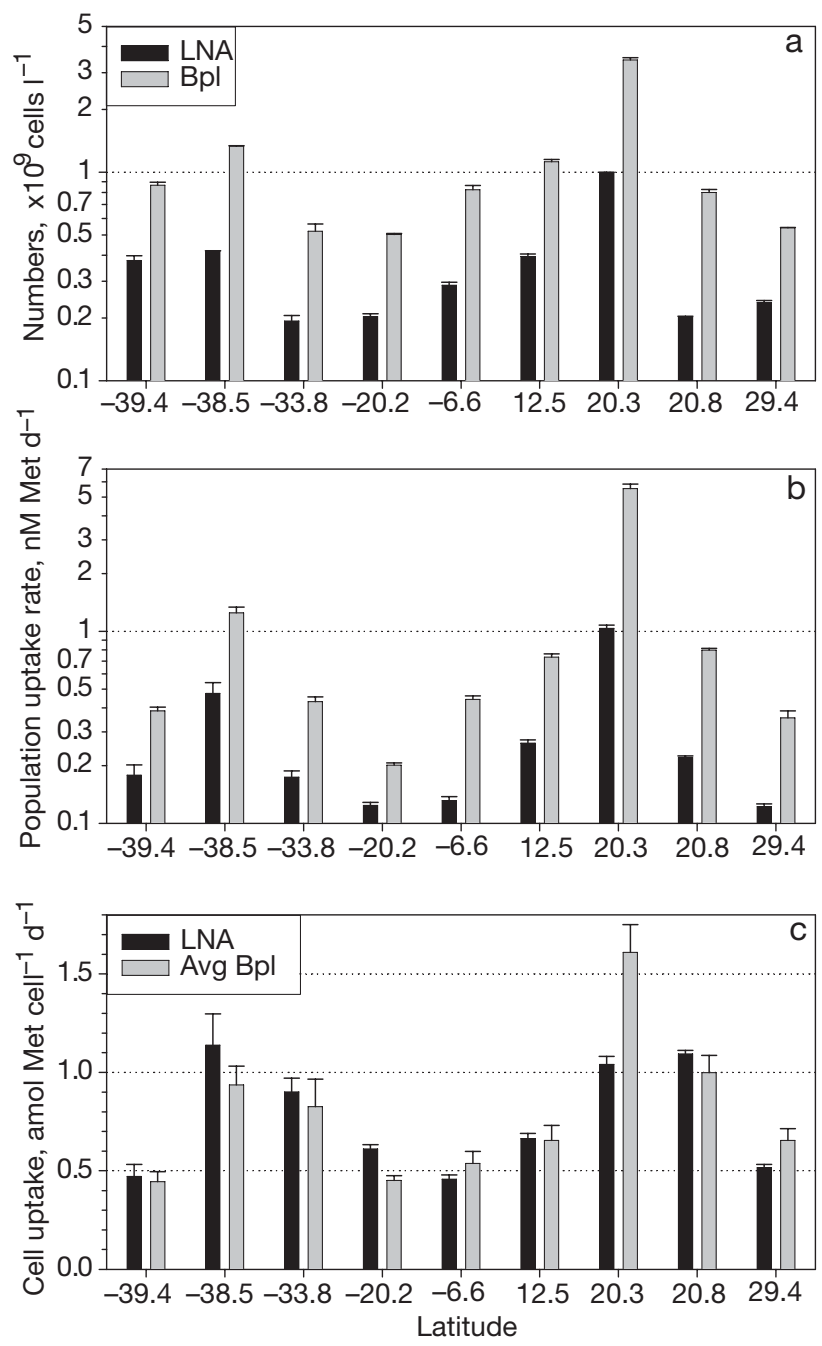

Fig. 4. Comparison of (a) absolute cell numbers, (b) population and (c) cell methionine (Met) uptake rates of low nucleic acid (LNA)-sorted cells and total bacterioplankton (Bpl) at different latitudes (negative values on $\mathrm{X}$-axis correspond to

$\left.{ }^{\circ} \mathrm{S}\right)$ along transect AMT-13. Data are means + SD

SAR11 dominance in the LNA group was predictable, particularly since the SAR11 cells are characterised by a small genome size of about 1.3 million base pairs (Mbp) (Giovannoni et al. 2005) compared to approximately 3 to $6 \mathrm{Mbp}$ for other Bpl cells, and the difference between the green fluorescence of DNAstained average LNA and HNA cells was approximately 5- to 6-fold (Fig. 2; note log scale). The SAR11 bacteria are reported to be a truly ubiquitous clade, found throughout the world ocean, where they account for about $25 \%$ of all microbial cells (Morris et al. 2002). The present study has shown that SAR11 dominates the flow-sorted LNA group in various surface waters of the Atlantic Ocean. While it was not surprising to find SAR11 dominating the LNA fraction, it was surprising to find this dominance constant across the Atlantic Ocean despite pronounced differences in absolute abundance in the different waters (Fig. 4a). Throughout the transect we found high amino acid uptake by the LNA fraction. This is in agreement with current knowledge that SAR11 bacteria play a significant role in nutrient cycling in the ocean (Malmström et al. 2004, 2005, Giovannoni et al. 2005). We cannot yet assign the Met uptake of LNA cells entirely to SAR11 cells, since it is probable that part of the uptake is by the other 20 to $40 \%$ prokaryotes (predominantly bacteria) comprising the LNA group. The notable compositional and functional constancy of the LNA bacterioplankton across the Atlantic Ocean suggests that the LNA group is a functionally distinct assemblage of cells specialised in efficient uptake of dissolved small organic molecules in the open ocean.

Acknowledgements. This work forms part of the Natural Environment Research Council (NERC) Marine and Freshwater Microbial Biodiversity Program (NER/T/S/2000/01424), with partial support from the NERC Atlantic Meridional Transect Consortium programme (NER/O/S/2001/00680), NERC core science programmes at the Plymouth Marine Laboratory and the National Oceanography Centre, Southampton, from the Max Planck Society, Germany, and from the EU project BASICS grant EVK3-CT-00078. The research of M.V.Z. was supported by an NERC advanced research fellowship (NER/I/ S/2000/00898).

\section{LITERATURE CITED}

Amann RI, Krumholz L, Stahl DA (1990) Fluorescentoligonucleotide probing of whole cells for determinative, phylogenetic, and environmental studies in microbiology. J Bacteriol 172:762-770

Belkin IM, Gordon AL (1996) Southern Ocean fronts from the Greenwich meridian to Tasmania. J Geophys Res 101:3675-3696

Daims H, Brühl A, Amann R, Schleifer KH, Wagner M (1999) The domain-specific probe EUB338 is insufficient for the detection of all bacteria: development and evaluation of a more comprehensive probe set. Syst Appl Microbiol 22:434-444

Eilers H, Pernthaler J, Peplies J, Glöckner FO, Gerdts G, Amann R (2001) Isolation of novel pelagic bacteria from the German Bight and their seasonal contributions to surface picoplankton. Appl Environ Microbiol 67:5134-5142

Field KG, Gordon D, Wright T, Rappe M, Urbach E, Vergin K, Giovannoni SJ (1997) Diversity and depth-specific distribution of Sar11 Cluster rRNA genes from marine planktonic bacteria. Appl Environ Microbiol 63:63-70

Fuchs BM, Woebken D, Zubkov MV, Burkill PH, Amann R (2005) Molecular identification of picoplankton populations in contrasting waters of the Arabian Sea. Aquat Microb Ecol 39:145-157

Gasol JM, Zweifel UL, Peters F, Fuhrman JA, Hagström ^̊ (1999) Significance of size and nucleic acid content heterogeneity as measured by flow cytometry in natural planktonic bacteria. Appl Environ Microbiol 65: $4475-4483$ 
Giovannoni SJ, Britschgi TB, Moyer CL, Field KG (1990) Genetic diversity in the Sargasso sea bacterioplankton. Nature 345:60-63

Giovannoni SJ, Tripp HJ, Givan S, Podar M and 10 others (2005) Genome streamlining in a cosmopolitan oceanic bacterium. Science 309:1242-1245

Glöckner FO, Amann R, Alfreider A, Pernthaler J, Psenner R, Trebesius K, Schleifer KH (1996) An in situ hybridization protocol for detection and identification of planktonic bacteria. Syst Appl Microbiol 19:403-406

Heywood JL, Zubkov MV, Tarran GA, Fuchs BM, Holligan PM (2006) Prokaryoplankton standing stocks in oligotrophic gyre and equatorial provinces of the Atlantic Ocean: evaluation of inter-annual variability. Deep-Sea Res II 53:1530-1547

Lebaron P, Servais P, Agogué H, Courties C, Joux F (2001) Does the high nucleic acid content of individual bacterial cells allow us to discriminate between active cells and inactive cells in aquatic systems? Appl Environ Microbiol 67:1775-1782

Li WKW, Jellett JF, Dickie PM (1995) DNA distributions in planktonic bacteria stained with TOTO or TO-PRO. Limnol Oceanogr 40:1485-1495

Malmström RR, Kiene RP, Cottrell MT, Kirchman DL (2004) Contribution of SAR11 bacteria to dissolved dimethylsulfoniopropionate and amino acid uptake in the North Atlantic ocean. Appl Environ Microbiol 70: 4129-4135

Malmström RR, Cottrell MT, Elifantz H, Kirchman DL (2005) Biomass production and assimilation of dissolved organic matter by SAR11 bacteria in the northwest Atlantic ocean. Appl Environ Microbiol 71:2979-2986

Manz W, Amann R, Ludwig W, Wagner M, Schleifer KH (1992) Phylogenetic oligonucleotide probes for the major subclasses of proteobacteria: problems and solutions. Syst Appl Microbiol 15:593-600

Manz W, Amann R, Ludwig W, Vancanneyt M, Schleifer KH (1996) Application of a suite of 16S rRNA-specific oligonucleotide probes designed to investigate bacteria of phylum Cytophaga-Flavobacter-Bacteroides in the natural environment. Microbiology 142:1097-1106

Marie D, Partensky F, Jacquet S, Vaulot D (1997) Enumeration and cell cycle analysis of natural populations of marine picoplankton by flow cytometry using the nucleic acid stain SYBR Green I. Appl Environ Microbiol 63: 186-193

Morris RM, Rappe MS, Connon SA, Vergin KL, Siebold WA, Carlson CA, Giovannoni SJ (2002) SAR11 clade dominates

Editorial responsibility: Gerhard Herndl, Den Burg, Texel, The Netherlands ocean surface bacterioplankton communities. Nature 420 : $806-810$

Neef A (1997) Application of in situ identification of bacteria to population analysis in complex microbial communities. PhD thesis, Technical University of Munich

Pernthaler A, Amann R (2004) Simultaneous fluorescence in situ hybridization of mRNA and rRNA in environmental bacteria. Appl Environ Microbiol 70:5426-5433

Pernthaler A, Pernthaler J, Amann R (2002) Fluorescence in situ hybridization and catalyzed reporter deposition for the identification of marine bacteria. Appl Environ Microbiol 68:3094-3101

Rappe MS, Connon SA, Vergin KL, Giovannoni SJ (2002) Cultivation of the ubiquitous SAR11 marine bacterioplankton clade. Nature 418:630-633

Roller C, Wagner M, Amann R, Ludwig W, Schleifer KH (1994) In situ probing of Gram-positive bacteria with high DNA $\mathrm{G}+\mathrm{C}$ content using 23S rRNA-targeted oligonucleotides. Microbiology 140:2849-2858

Tarran GA, Heywood JL, Zubkov MV (2006) Latitudinal changes in the standing stocks of nano- and picoeukaryotic phytoplankton in the Atlantic Ocean. Deep-Sea Res II 53:1516-1529

Zubkov MV, Tarran GA (2005) Amino acid uptake of Prochlorococcus spp. in surface waters across the South Atlantic Subtropical Front. Aquat Microb Ecol 40:241-249

Zubkov MV, Fuchs BM, Archer SD, Kiene RP, Amann R, Burkill PH (2001a) Linking the composition of bacterioplankton to rapid turnover of dissolved dimethylsulphoniopropionate in an algal bloom in the North Sea. Environ Microbiol 3:304-311

Zubkov MV, Fuchs BM, Burkill PH, Amann R (2001b) Comparison of cellular and biomass specific activities of dominant bacterioplankton groups in stratified waters of the Celtic Sea. Appl Environ Microbiol 67:5210-5218

Zubkov MV, Fuchs BM, Tarran GA, Burkill PH, Amann R (2002) Mesoscale distribution of dominant bacterioplankton groups in the northern North Sea in early summer. Aquat Microb Ecol 29:135-144

Zubkov MV, Fuchs BM, Tarran GA, Burkill PH, Amann R (2003) High rate of uptake of organic nitrogen compounds by Prochlorococcus cyanobacteria as a key to their dominance in oligotrophic oceanic waters. Appl Environ Microbiol 69:1299-1304

Zubkov MV, Tarran GA, Fuchs BM (2004) Depth related amino acid uptake by Prochlorococcus cyanobacteria in the Southern Atlantic tropical gyre. FEMS Microbiol Ecol 50:153-161

Submitted: February 16, 2006; Accepted: July 18, 2006 Proofs received from author(s): November 10, 2006 